\title{
Renegotiating Debt: Chemical Governance and Money in the Early Nineteenth-Century Dutch Empire
}

\author{
Andreas Weber
}

When Johannes Goldberg, head of the Netherlands' Department of Trade and Colonies (Departement van Koophandel en Koloniën), left his office in The Hague's city center in early spring 1816, he was full of expectations. After months of reflecting on how to mitigate the high level of debt accrued from the colonies in Southeast Asia, he had just dispatched instructions for a complete monetary reform program to the governor general in Batavia, the administrative seat of the Dutch in the Indonesian Archipelago. ${ }^{1}$ Since the demise of the former Dutch East India Company (Voc) in 1799, colonial debt had become a heavy burden for the Dutch treasury. ${ }^{2}$ Goldberg hoped that the introduction of a new currency, the colonial guilder, would help resolve this problem by capitalizing on Java and the neighbouring islands' agricultural wealth. ${ }^{3}$ However, establishing trust in the new money in maritime Southeast Asia turned out to be a challenging endeavor, not least because the actual realization of monetary policy depended on the practices of locally situated mint masters, assayers and other chemical practitioners who engaged with the production and circulation of paper notes and metal coins both at home and in the colonies. This essay demonstrates that, instead of simply serving their metropolitan masters, these historical actors and material objects had a direct hand in shaping imperial policies through their involvement in localized processes of chemical governance.

As explained in the introduction to this volume, the concept of chemical governance enables us to follow the various ways in which chemical knowl-

1 The report, which is dated 12 March 1816 , and all additional material is now stored at the National Archive [=NA], The Hague, collectie Goldberg, 162.

2 On the tremendous public debt after the Napoleonic Wars, Wantje Fritschy, De patriotten en de financiën van de Bataafse Republiek. Hollands krediet en de smalle marges voor een nieuw beleid (1795-1801) ('s-Gravenhage: Stichting Hollandse Historische Reeks, 1988), 40-41.

3 The idea of using a new currency to renegotiate debt has a long history and goes at least back to China in the ninth century AD. Philip Coggan, Paper Promised: Debt, money and the new world order (New York: Public Affairs, 2012).

(C) ANDREAS WEBER, 2018 | DOI 10.1163/9789004325562_010

This is an open access chapter distributed under the terms of the CC-BY-NC License. 
edge, know-how and substances were harnessed - sometimes in quite mundane ways - to realize the mediating embodiment of policy-making measures. In some cases this entailed the experimental construction of material standards and instruments for the policing of commodities through tests for 'purity' and adulteration, or the establishment of excise and taxation regimes. ${ }^{4}$ In other cases, such as that examined in this essay, it entailed the production of objects that materialized systems of value and exchange, enabling the instantiation and authorization of these systems through the combination of their mobility and durability, on one hand, and leaving them subject to local negotiation and appropriation on the other.

By approaching Goldberg's monetary reform through the lens of chemical governance, this essay develops two closely related components discussed in this volume's introduction. First, it draws attention to the activities of actors whose practices and products were mundanely responsible for giving materialized form and substance to policies. Chemistry and knowledge of materials turned out to be critical to what might appear to be a rather abstract financial policy. Putting their specialized knowledge and skills regarding inks, papers and alloys to work, mint masters and assayers translated initial policy pronouncements into the notes and coins whose circulation determined how policies actually unfolded. This meant that those who engaged in chemical practices on a more local level - away from metropolitan centers - could nonetheless exert formative influence over global policies. This chapter moves outside Europe to show that processes of chemical governance were by no means confined to the European stage. Far from simply enabling or constraining policy enforcement, this essay argues, the locally made choices of metallic composition, symbolic decoration and the like ascribed values to currency that might differ from those which were originally conceived in the metropolitan capital. ${ }^{5}$

This account adds a chemical element to Michel Foucault's notion that power is better seen operating in geographically complex fields of operation than via the hands of a few government ministers and administrators. Power does not reside in individuals but is dispersed, in this case through varied acts

4 Joppe van Driel and Lissa Roberts, "Circulating Salts: Chemical governance and the bifurcation of "nature" and "society," Eighteenth-Century Studies 49 (2016): 233-263; William Ashworth, Customs and Excise: Trade, production and consumption in England, 1640-1845 (Oxford: Oxford University Press, 2003).

5 Referencing the work of Madeleine Akrich, Michel Callon writes succinctly, "Without the material device the operating instructions are meaningless." Michel Callon, "What Does it Mean to Say that Economics is Performative?," csI Working Papers Series 5 (2006): 1-58, on 12. 
of circulating and manipulating materials. ${ }^{6}$ In place of considering the metropolitan state as the centralized motor of empire building, this essay reveals the geography of policymaking's practical field to have been polycentric and rooted in decisions about materials. At the same time, however, the decentralized character of imperial policymaking was often obscured. The outcomes of local initiatives and acts of appropriation, which shaped the realization of policy, became associated - for better or worse - with the metropolitan actors under whose policy jurisdiction they officially fell. While chemical practice could thus alter the content and consequences of centrally conceived policy and policymakers, it takes effort to recover its traces. ${ }^{7}$

Goldberg's responsibilities for the establishment and policing of colonial policy began in 1814 when the Dutch king asked him - he was at that time head of the Court for Commerce in The Hague (Rechtbankvan Koophandel) - to set up and instruct a new colonial government in Batavia. Following the British occupation of Batavia between 1811 and 1815, Willem I and his advisors hoped that Goldberg's expertise and skill as an administrator would help turn the colonies into a financially rewarding annex of the Dutch kingdom. ${ }^{8}$ Similar to the French revolutionary government's decision to introduce assignats - the French revolutionary currency with which Antoine-Laurent Lavoisier was involved - two decades before, the Dutch king requested Goldberg to introduce a new paper currency in the colonies. Goldberg and the Crown hoped that the colony's proto-bankers would accept this new currency in exchange for silver and gold coins that could be used to pay colonial debts at home. In order to endow Goldberg with the authority and status to master this challenge, the king not only installed him as the well-paid head of the Netherlands' Department of Trade and Colonies but also made him a member of the Dutch nobility. Within a couple of months, Goldberg became one of Willem I's most

6 Michel Foucault, Power/Knowledge: Selected interviews and other writings, 1972-1977 (New York: Pantheon, 1980).

7 As such, the chapter might be seen as a chemical version of Michel de Certeau's celebrated account of resistance in Michel de Certeau, The Practice of Everyday Life, trans. Steven Rendall (Berkeley: University of California Press, 1984).

8 For the Dutch king's high expectations regarding the colony's revenue, see Thomas Stevens, Van der Capellen's koloniale ambitie op Java. Economisch beleid in een stagnerende conjunctuur, 1816-1826 (Amsterdam: Historisch Seminarium van de Universiteit van Amsterdam, 1982), 216219; For Goldberg's earlier involvement in organizing the monetary system at home, see Roland Uittenbogaard, Evolution of Central Banking? De Nederlandsche Bank 1814-1852 (Dordrecht: Springer 2015), 50-55. 
important advisors regarding the management of Dutch possessions in the Indonesian Archipelago. ${ }^{9}$

As in the history of assignats, Goldberg's monetary reform program points to the inherently political nature of administrative expertise. Again similar to Lavoisier, Goldberg was confronted with the following challenge: how to convince proto-bankers and plantation owners in the colonies to link their private capital to that of the Dutch state, which faced heavy colonial debts? ${ }^{10}$ Ironically, perhaps, there was a fundamental difference between their chosen solutions. Lavoisier considered paper money issued by a privately owned bank as the best solution to mitigate debt. Goldberg, on the other hand, opted for a program that was inseparably composed of chemical and political components. In order to convince the colony's proto-bankers to accept the new currency, Goldberg saddled the colonial government with the task of supplementing the introduction of his new paper money - in total six million guilders - with specially minted silver and copper coins. As Goldberg put it, only if the colonial government were able to prove publicly and repeatedly its ability to exchange paper money for silver and copper coins would the colony's proto-bankers gradually accept the new currency as a trustworthy medium of exchange. ${ }^{11} \mathrm{In}$ practice, this meant that establishing trust in the new currency rested on gaining the support and cooperation of mint masters, assayers, skilled artisans and wealthy investors.

In the end, Goldberg's efforts led to little. Owing to his inability to recruit and control local chemical expertise, the entire project turned out to be a costly failure. Instead of stabilizing his position as one of the main voices in Willem I's inner circle of advisors, Goldberg found himself shifted to a less influential position as the king decided to dissolve the Department of Trade and Colonies. ${ }^{12}$ As a consequence, Goldberg continuously suffered from severe financial problems. Even after his death, his family was exposed to creditors claiming money from his bequest. ${ }^{13}$

W.M. Zappey, De economische en politieke werkzaamheid van Johannes Goldberg (Brussels: N. Samson, 1967), 99-100.

On Lavoisier's involvement in developing a new currency in France, see Charles Gillispie, Science and Polity in France: The revolutionary and Napoleonic years (Princeton: Princeton University Press, 2004), 84-86. For a more recent analysis, see Rebecca Spang, Stuff and Money in the Time of the French Revolution (Cambridge, MA: Harvard University Press, 2015), chapter 2. NA The Hague, collectie Goldberg, 162A, letter Goldberg to General Committee (Commissie generaal), 's Gravenhage, 18 March 1816. Ibid., p. 193 . 
By analysing Goldberg's failure through the lens of chemical governance, this essay differs from other studies on scientific inquiry in the context of the early nineteenth-century Dutch empire. ${ }^{14}$ While older numismatic scholarship has laid important groundwork, others have based their narratives on issues such as the diffusion and failure of 'enlightened' science in the colonial Indonesian Archipelago (Lewis Pyenson, Andrew Goss and Pieter Boomgaard). ${ }^{15}$ In particular Goss' attempt to separate 'science' and 'governance' analytically into two independent narratives has received scholarly criticism..$^{16}$ Boomgaard's approach is more nuanced but shares the disadvantage that it also relies on a normative notion of how science should have developed in the Indonesian Archipelago. For him, the key point is that the lack of metropolitan financial and organizational support led to a lack of 'scholarly excellence' in the early nineteenth-century Indonesian Archipelago. ${ }^{17}$ Unlike historians such as Pyenson, Goss and Boomgaard, this essay does not divide the analysis of governance and science into 'metropolitan' and local 'colonial' trajectories; neither is it interested in making normative judgments about 'scientific quality'. By conceptualizing chemical governance as a process in which chemical practice was used to intermediate between local interests (for example of mint masters and assayers) and goals formulated in Europe, this essay uses Goldberg's experience to shed light on the particularities through which chemical practice

For a similar use of the concept in a European context, see Van Driel and Roberts, "Circulating Salts" (see note 4).

For the first see John Bucknill, The Coins of the Dutch East Indies (London: Spink, 1931); Cornelis Scholten, De munten van de Nederlandsche gebiedsdelen oversee, 1601-1948 (Amsterdam: J. Schulman, 1951). For the latter see Lewis Pyenson, Empire of Reason. Exact sciences in Indonesia 1840-1940 (Leiden: Brill, 1989); Andrew Goss, The Floracrats. Statesponsored science and the failure of enlightenment in Indonesia (Madison: University of Wisconsin Press, 2011); Peter Boomgaard, ed., Empire and Science in the Making. Dutch colonial scholarship in comparative global perspective, 1760-1830 (New York: Palgrave Macmillan, 2013).

16 See, for instance, Robert E. Elson's review of The Floracrats in the American Historical Review 116 (2011): 1469 and Robert-Jan Wille, "The Coproduction of Station Morphology and Agricultural Management in the Tropics: Transformations in botany at the botanical garden at Buitenzorg, Java 1880-1904," Denise Phillips and Sharon Kingsland, eds., New Perspectives on the History of Life Sciences and Agriculture (Cham: Springer International Publishing, 2015), 253-275; For a criticism of Pyenson, see Paolo Palladino and Michael Worboys, "Science and Imperialism," Isis 84 (1993), 91-102. 
shaped governance in Europe and Southeast Asia in the early nineteenth century. ${ }^{18}$

To carry out this analysis, this essay focuses on two episodes of chemical governance. By zooming in on the production of the new money in the Netherlands, the first episode shows how Goldberg struggled to acquire local support for the introduction of a new currency. While the Haarlem printers Joh. Enschedé en Zonen considered Goldberg's governance scheme an ideal opportunity to capitalize on their accumulated chemical skills, the mint masters and assayers in Utrecht read it as a threat to their status and authority. In particular Goldberg's attempt to circumvent the Utrecht mint's monopoly by relying on a consortium of private manufacturers stirred tensions between the government and mint masters there.

While the mint in Utrecht openly refused to collaborate with Goldberg, the mint master and assayer in the Dutch East Indies chose a more subtle reaction, which provides the focus of this essay's second episode. Here, Goldberg's dream of reducing public debt in the Netherlands by introducing a new currency system in the colonies was transformed by the colonial mint master and assayer, who used chemical practices to appropriate his project for the pursuit of local interests. Taken together, the two episodes show that conferring authority over and value to money required a heavily managed and globally distributed process that was often built on quite mundane decisions about chemical practice.

\section{Co-operation and Resistance in the Netherlands}

The production of Goldberg's money first required chemical expertise in the Netherlands. While the national mint in Utrecht was tasked with producing silver and copper coins, the paper money was produced by the Haarlem company Joh. Enschedé en Zonen. Since 1795, the company regularly supplied the government with a large amount of promissory notes and paper bills..$^{19}$ It was

18 This definition resonates with what governance scholars have conceptualized as 'de facto' governance. See Arie Rip, "De Facto Governance of Nanotechnologies," Morag Goodwin, Bert-Jaap Koops, and Ronald Leenes, eds., Dimensions of Technology Regulation (Nijmegen: Wolf Legal Publishers, 2010), 285-308.

19 N.L.M. Arkestijn, "Met de bajonet op de keel. Inkopen met ongedekt papiergeld," in E.H.P. Cordfunke and H. Sarfatij, eds., Van Solidus tot euro: Geld in Nederland in economisch-historisch en politiek perspectief (Hilversum: Verloren, 2004), 139-146. For a broader history of the production of bank notes, see Colin Narbeth, Robin Hendy, and Christopher Stocker, Historische bankbiljetten en aandelen (Baarn: Moussault's Uitgeverij, 1979), 29-44. 
therefore relatively easy for Goldberg to activate the printer's support. The production of Goldberg's new currency in Haarlem emerged from negotiations involving chemical expertise and deep knowledge of different raw materials. In order to provide printers such as Joh. Enschedé en Zonen with suitable paper, paper manufacturers in Boxtel and the Zaan area had teamed up with a chemist in Amsterdam to develop and work with liquid bleaching agents that had been described by the French chemist Claude Louis Berthollet a few years before. ${ }^{20}$

The production of durable and whitish paper, which was compatible with different inks and letter types, was chemically challenging for paper makers and printers. While one-guilder notes were printed in black, higher denominations were printed in red and blue, requiring consideration of the substances used to make the colours. Some of the notes were marked with a printed stamp that had a reddish-brown colour (Fig. 8.1). ${ }^{21}$

Moreover, since some of the bills had to be signed by government officials in the colonies, the paper had also to be coated with a special layer of gelatin to keep the ink from bleeding. Solutions to these chemical problems demanded the establishment of highly disciplined spaces and personnel. In order to guard chemical and other expertise, the company erected a 'secret' print shop (Geheimdrukkerij) in 1795. Access to this branch of the company was only allowed for selected staff members who had sworn an oath to remain silent about the chemical composition of value-bearing papers. ${ }^{22}$

The production of the new silver and copper coins turned out to involve even more challenges. Chemical practitioners might unexpectedly cease to support policy demands. Initially, the Utrecht mint master confirmed his willingness to assist with Goldberg's plan and produced at least one sample of the new silver guilder (Fig. 8.2). But subsequently Utrecht became unwilling to cooperate. Following the dissolution of district mints in 1806 , the mint in Utrecht was the only site in the Netherlands where minting took place. When Goldberg requested Gideon Langerak Du Marchie Servaas, mint master in

20 NHA Haarlem, collection Van Gelder, inv. 1108: Proeven om bleekwater te vervaardigen (1813). Domestic paper money was apparently also printed on special paper. B.W. de Vries, De Nederlandse papiernijverheid in de negentiende eeuw ('s-Gravenhage: Martinus Nijhoff, 1957), 271.

For more details on the production of the bills, see Theo van Elmpt, Netherlands East Indies. Paper currency, 1815-1827 (Uithoorn: Elran Express, 2009), 1-44; A.M. van de Waal, "De oudste bankbiljetten. Eerste relatie van de Nederlandsche Bank met Joh. Enschedé en Zonen," Ontwikkelings- en ontspanningsvereniging "De Nederlandsche Bank" 8 (1953), 4-14. Frans Willem Lantink et al., Voor stad en staat, vol. 1: Plattegrond (Amsterdam: Joh. Enschedé, 2003), 42. 


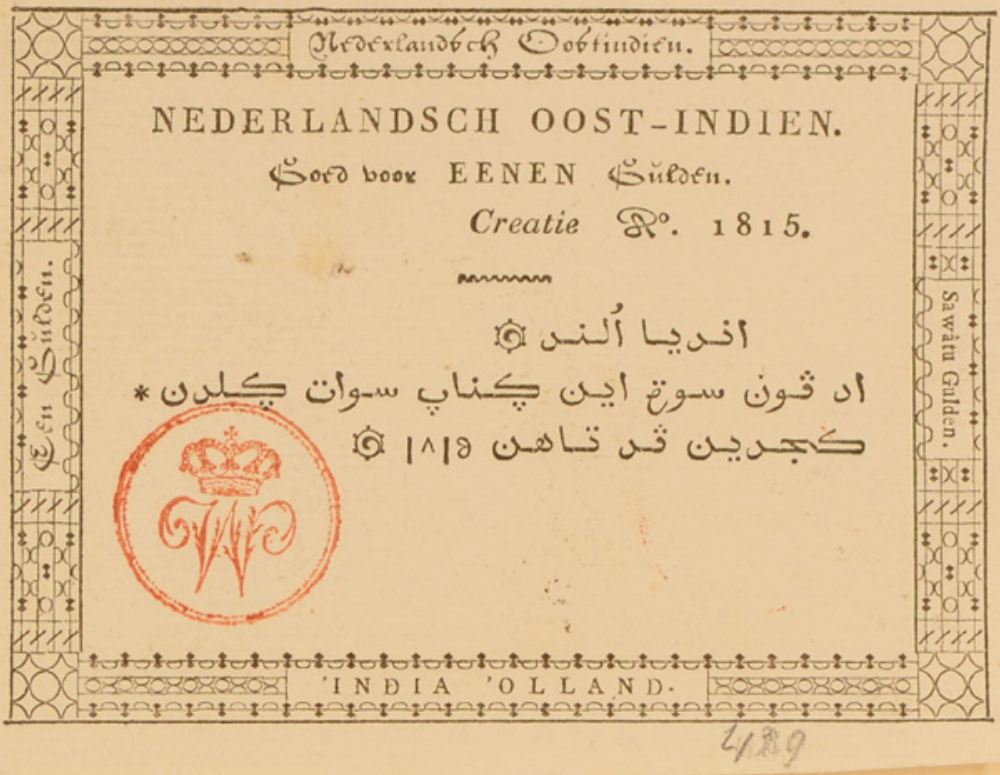

FIGURE 8.1 Sample of paper money with the value of one colonial guilder. The musical notation in the margin was based on a special letter type which the German type cutter J.M. Fleischmann had developed exclusively for Johan Enschedé in Haarlem in the 177os. (NA The Hague, collectie Goldberg, inv. 162). IMAGE PUBLISHED UNDER CC-BY BY THE NATIONAL ARCHIVE, THE HAGUE.

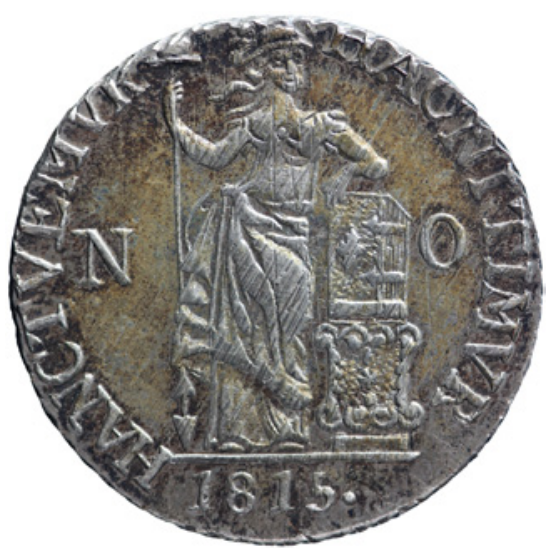

FIGURE 8.2

Sample of new 'colonial' guilder produced at the mint in Utrecht in 1814 or 1815 . IMAGE USED BY THE KIND PERMISSION OF DE NEDERLANDSCHE BANK. 
Utrecht from 1797, to produce the necessary silver alloy, the latter rejected the order by referring to the mint's limited capacity. ${ }^{23}$

While historians have simply reiterated the mint's claim of limited capacity as a valid explanation, it seems more likely that the mint master's rejection mirrors growing friction between the government and the mint. ${ }^{24}$

At the time when Goldberg began searching for producers of the new silver coins, tensions between the mint in Utrecht and the government in The Hague were rising. In particular, the government's decision to request that a consortium of private entrepreneurs take on the production and minting of copper coins irritated Yman Dirk Christiaan Suermondt, who had succeeded Du Marchie Servaas as mint master in $1815 .{ }^{25}$ The consortium included the Amsterdam silversmith Hendrik de Heus, who had previously produced 175 tons of copper coins for the Southeast Asian colonies in 1802, and copper millers from the Veluwe. ${ }^{26}$ In the course of 1815 they produced thirty-five tons of copper coins for a price that undercut the Utrecht mint. ${ }^{27}$ De Heus could offer low prices since he had successfully equipped his workshop with steam driven machinery for the flattening of coins. Circumventing the mint's monopoly was not a new phenomenon, for Suermondt and his colleagues in Utrecht had previously complained about the government's decision to hire private entrepreneurs instead of supporting their monopoly. ${ }^{28}$

The mint's growing resistance against Goldberg's plan to produce a new currency created other governance challenges. While paper money with the value of one guilder in the metropole was officially backed with silver coins containing 9.614 gram of fine silver, Goldberg struggled to determine the colonial

23 For a good contextualization, see Marcel van der Beek, "'s Rijks Munt en de aanmuntingen door De Heus," De Beeldenaar 2 (1995): 357-366.

24 For the first see, for instance, Copius Hoitsema and F. Feith, De Utrechtsche munt uit haar verleden en heden (Utrecht: Oosthoek, 1912).

Pieter Hendrik van der Kemp, De teruggave der Oost-Indische koloniën 1814-1816 ('s-Gravenhage: M. Nijhoff, 1910), 234; Pieter Hendrik van der Kemp, "Episodes uit de geschiedenis der aanmuntingen ten behoeve van Oost-Indië, 1802-1807," Bijdragen tot de taal-, land- en volkenkunde van Nederlandsch-Indië 70:2 (1915): 227-440, 310.

26 J. MacLean, "Koperindustrie in Nederland, 1750-1850," Economisch en social-historisch jaarboek 43 (1971): 39-63, 42.

27 Van der Kemp, "Episodes uit de geschiedenis," pp. 331-338 (see note 25). On Van Heus and his company, see H.A. Diederiks, "Hendrik de Heus. Een Amsterdamse ondernemer in het begin van de 19e eeuw," Amstelodamum 56 (1969): 58-65, and MacLean, "Koperindustrie in Nederland," pp. 39-63 (see note 26). For a fascinating micro-history of one of the involved copper mills in the Veluwe, see Henri Slijkhuis, De kopermolen in Zuuk (Vorchten: De Bekenstichting, 2015).

28 Van der Kemp, “Episodes uit de geschiedenis," pp. 288-300 (see note 25). 
equivalent. ${ }^{29} \mathrm{He}$ wished to avoid a situation whereby the new coins would simply end up in China and other parts of Asia where the silver was used for artwork or religious purposes. Eventually Goldberg advised the Dutch crown to produce silver guilders, which contained about 20 percent less fine silver than the ones which were used in the Netherlands. ${ }^{30}$ Owing to the aforementioned tensions with the mint in Utrecht, he chose not to base this decision on the expertise of the mint master. Neither did he turn to Willem Adriaan Arnold Poelman, inspector and assayer general in Utrecht since 1814. Poelman, who had served previous governments as a mint expert, only assayed two colonial silver coins for Goldberg. ${ }^{31}$ Since these coins had been produced in the years before the British took over Java in 1811, the mint's assay did not help Goldberg to assess the current situation in Java. Resistance from chemical practitioners led Goldberg to rework his plans. Instead of drawing upon Poelman's experience and contacts with metal traders, assayers and inspectors of weights and measures in Batavia, Goldberg chose to base his decision on policy documents taken from the archives of the Voc and the Council for the Asian Possessions and Establishments (Raad der Aziatische Bezittingen en Etablissementen), which contained the opinions of former colonial government officials. ${ }^{32}$

In turn, Du Marchie and Poelman's reluctance to support Goldberg cannot be justified by referring to the technical complexity of the chemical examination of coins. Although assays could sometimes take several days, they involved a standard technique of precision which mint masters usually employed in

29 Jean Hendrik van Swinden, Bedenkingen over het muntwezen (Utrecht: Het Geldmuseum, 1997; transcription of an unpublished manuscript dated 1815), 11.

$30 \quad$ For the first see Willem G. Wolters, "The 'Doit Infestation in Java': Exchange rates between silver and copper coins in Netherlands India in the period, 1816-1854," in Hans Ulrich Vogel, ed., Money in Asia (1200-19oo): Small currencies in social and political contexts (Leiden: Brill, 2015), 108-139, 126-127. Pieter Hendrik van der Kemp, "De NederlandscheIndische proefgulden van 1815," Tijdschrift voor munt- en penningkunde (1913): 21-60, 24 labels Goldberg's decision as "unnatural."

$31 \quad$ For a short biography of Poelman, see Albert A.J. Scheffers, "Om de kwaliteit van het geld. Het toezicht op de muntproductie in de Republiek en de voorziening van kleingeld in Holland and West-Friesland in de achttiende eeuw" (PhD diss., Leiden University, 2013), vol. 2, 443-444.

For the global character of material expertise see Albert A.J. Scheffers, "Johan Sebastiaan van Naamen, Muntmeester van Batavia 1764-1768 en Utrecht 1782-1797 in perspectief," De Muntkoerier 42 (2013): 18-19; and Simon Schaffer, "Assay Instruments and the Geography of Precision on the Guinea Trade," Marie-Noëlle Bourget, Christian Licoppe and H. Otto Sibum, eds., Instruments, Travel and Science. Itineraries of precision from the seventeenth to the twentieth century (London: Routledge, 2002), 20-50. 
their small laboratories. ${ }^{33}$ The result of the assay depended heavily on the availability of bone ash cupels and precise balances which were used to weigh the coin material before and after the analysis. ${ }^{34}$ In order to separate fine silver from copper and other base metals, the assayer melted each of the coins and then put them together with a piece of lead in a cupellation furnace, designed for high temperatures. After the oxidation and evaporation of the base metals, the remaining piece of fine silver ('koninkje') was then soaked in nitric acid in order to remove the last remnants of other materials. By comparing the weight of the koninkje with the weight of the original coin, assayers were able to calculate the metal content of the assayed coins.

Owing to the lack of additional information, the Dutch crown simply followed Goldberg's advice. After Willem I decided to circulate two coins (one domestically, the other in the Indonesian Archipelago) with the same denomination and weight but with a different content of silver, another governance challenge arose. ${ }^{35}$ Although the king had reserved sufficient funds for the new money, Goldberg now struggled to find a suitable production facility. Since his initial plan to rely on the mint in Utrecht for producing silver coins did not materialize, he opted to delegate the production to the colonial mint in Surabaya on the Northeast Coast of Java. Although the Surabaya mint had only limited experience in supplying the colonies with coins, a frustrated Goldberg could do nothing more than order the colonial government in Batavia to start the minting as quickly as possible. Goldberg now had to engage with the materials of chemical practice himself in order to carry through his policy. To facilitate the production of coins in Java, Goldberg added additional minting equipment, such as castings for the production of the dies and pencil drawings to the shipment of metal he sent to get things started. ${ }^{36}$ Chemical practitioners added further frustration to this plan. When Goldberg tried to send the Utrecht die cutter J.P. Schouberg with the silver to Batavia, Schouberg claimed that his health would not allow him to travel to Java. ${ }^{37}$

33 For a description of the process, see Scheffers, "Om de kwaliteit," vol. 1, pp. 131-134 (see note 31); and John S. Forbes, Hallmark. A History of the London Assay Office (London: The Goldsmith's Company, 1999), 20-24.

34 For an in-depth study on gold and silver balances, see Michael A. Crawforth, Weighing Coins: English folding gold balances of the 18th and 19th centuries (London: Cape Horn Trading, 1979). Contemporary assay manuals stress the importance of precise assay balances and equal cupels. Louis N. Vauquelin, Manuel de l'essayeur (Paris: Chez le citoyen Bernard, 1799), 6-14 and 21-24.

36 Van der Kemp, “De Nederlandsche-Indische proefgulden," pp. 33-34 (see note 30).

37 Ibid. 
As the next section demonstrates, similar problems beset Goldberg's scheme once production was transferred abroad. Instead of simply following Goldberg's orders, the mint in Surabaya and Batavia's colonial administrators became entangled in a struggle regarding the new money's composition and management. The acts of chemical practitioners operating within a complex local political environment then proved transformative for the realization of Goldberg's distantly formulated policy.

\section{Balancing Interests in Surabaya}

When Goldberg's currency arrived in Java, the colonial government in Batavia was in an ambiguous position. On the hand, there were 'men on the spot' who wished to follow Goldberg's orders and add the crates of bills and barrels of coins to the local circulation. ${ }^{38}$ On the other hand, Goldberg's plan met severe local resistance from the colony's elite. Material concerns over silver content were at the heart of these anxieties. While Goldberg considered the low silver content of his coins as a tool for preventing them from draining off to other parts of Asia, the local elite feared that it would devalue the local currency the rupee - which had a much higher silver content. According to British regulations, one rupee in Java had to contain 10.896 gram of fine silver, which is almost 30 percent more than Goldberg's coins. ${ }^{39}$ Since the introduction of new money formed a serious threat to locally accumulated capital, it is unsurprizing that there was resistance. Many local elites had profited heavily from the export of cash crops such as coffee, indigo and sugar, which they produced on their large private estates in the hinterland of Batavia. ${ }^{40}$ With those profits

38 John S. Galbraith introduced the term 'man on the spot' in his pioneering attempt to understand the active role played by locally situated colonial administrators who sought to represent colonial rule in a context of required readiness to respond to local exigencies. See John S. Galbraith, "The 'Turbulent Frontier' as a Factor in British Expansion," Comparative Studies in Society and History 2 (1960): 150-168.

Pieter Hendrik van der Kemp, "De zilveren Java-Ropijen van de jaren 1816-1817," Bijdragen tot de Taal-, Land- en Volkenkunde van Nederlandsch-Indië 67 (1913): 275-366, 304; N.P. van den Berg, De kwestie over den geldsomloop in Nederlandsch-Indië (Batavia: H.M. van Dorp, 1863), 63-66.

40 On the importance of British, American and Chinese merchants in the region, see J.R. Fichter, So Great a Proffit. How the East India trade transformed Anglo-American capitalism (Cambridge, MA: Harvard University Press, 2010), chapters 3-6; Leonard Blussé, Visible Cities. Canton, Nagasaki, and Batavia and the coming of the Americans (Cambridge, MA: Harvard University Press, 2008), 6o-64. 
now threatened, conflicts and negotiations would ensue over how the colony's mint should go about assaying and producing new coins. Chemical practice thus again became the focus around which Goldberg's policy would be enacted, resisted and revised.

Local resistance and redirection came in different guises. When news about Goldberg's monetary reform program spread in Java in late 1816, Batavia's merchant elite gently reminded the colonial government that money with the name of guilders was unknown in the area. Two earlier attempts to produce and circulate 'guilders' had remained on a small scale and had been shortlived. ${ }^{41}$ Moreover, they hinted that the introduction of a new currency would further threaten the local population's belief in the government's ability to act as a trustworthy broker of value. In particular, their fears were grounded in the precedent set by earlier British attempts to issue copper coins of inferior quality, which had destabilized the situation in Java. ${ }^{42}$

Since the colonial government depended on the support of these elite merchants - many of whom also held high administrative positions - colonial government representatives eventually agreed with some of their concerns and decided to opt for a compromise. In order to counter their fears of devaluation, the colonial government made two important changes to Goldberg's plan. First it decreed that the raw silver which had been shipped at Goldberg's behest should be used to produce silver rupees rather than silver guilders. Moreover, they ordered the colony's mint master to increase the rupee's content of fine silver to 9.6 grams - a value which split the difference between what Goldberg had expected them to be (7.968 grams) and the local norm (10.896 grams). ${ }^{43}$ Since silver coins in the Netherlands also contained 9.6 gram of silver, the colonial government thus hoped that this compromise would also be well received at home.

$41 \quad$ Van der Kemp, “De zilveren Java-Ropijen,” pp. 291-292 (see note 39).

42 ANRI Jakarta, Arsip Varia (K 64), Stukken betreffende het muntwezen, box 2, varia 191: Resident of Rembang to colonial government, 16 July 1825; J.P. Moquette, "De munten van Nederlandsch-Indië," Tijdschrift voor Indische Taal-, Land- en Volkenkunde 51 (1909): 33-56, 37; For an initial glimpse into the complexity of the trade networks in the region with a special focus on coinage, see Li Tana, "Cochinchinese Coin Casting and Circulating in Eighteenth-Century Southeast Asia," in Eric Tagliacozzo and Wen-chin Chang, eds., Chinese Circulations. Capital, commodities, and networks in Southeast Asia (Durham: Duke University Press, 2011), 130-148.

Van der Kemp, "Episodes uit de geschiedenis," p. 396 (see note 25). 
At the time when Goldberg's silver arrived in Surabaya in mid-1816, the city's mint was poorly set up for producing government coinage. ${ }^{44}$ According to a survey done during the British interregnum in 1811 or 1812, the facility consisted of a smelting house $(290 \times 56$ feet $)$, three sheds with screw presses and other machines imported from Europe, flattening mills and a chemical workplace for the material analysis of raw materials and coins. ${ }^{45}$ In those years, coinage equipment circulated regularly between Europe, Asia and the Americas. Matthew Boulton's workshop in Birmingham, for instance, supplied a wide range of coinage facilities in Europe, India, South America and Russia with tools and equipment. ${ }^{46}$ Like the mint in Utrecht, the Surabaya mint was equipped with small iron assay furnaces, glassware, pans for distillation, touchstones, and several sets of balances and weights (Fig. 8.3). ${ }^{47}$

By 1816 production at the Surabaya mint heavily depended on private minting requests from the colony's elite. Orders were as likely to come from military men and Javanese aristocrats as local government officials. ${ }^{48}$ In fact, the production volume for privately minted coins often surpassed production for the government. Whereas the Surabaya mint master and assayer Johan Anthonie Zwekkert manufactured 36,762 coins for the government in 1814, the following year the mint produced around 50,000 silver rupees for private individuals. ${ }^{49}$

For Zwekkert, the introduction of Goldberg's currency was thus a doubleedged sword. On the one hand, processing a relatively large amount of silver would be a lucrative endeavor; he was allowed to keep 5 percent of the total amount of fine silver as his salary, next to expenses for the necessary labor force and equipment. ${ }^{50}$ On the other hand, the introduction of a new currency

44 On the mint's history, see Elisa Netscher and Jacobus A. van der Chijs, De munten van Nederlandsch-Indië (Batavia: Lange \& Co., 1863), appendix 2: Geschiedenis van de munt in Soerabaja; L.M.J. Boegheim, "François Loriaux, de stichter van de Duitenmunt te Soerabaja," De Beeldenaar 3 (1996): 131-134. On Loriaux, see also Van der Kemp, "Episodes uit de geschiedenis," pp. 250-59 (see note 25).

Bucknill, The Coins, pp. 161-172 (see note 15) and J.P. Moquette, “De munten," p. 35 (see note 42 ).

46 Denis R. Cooper, The Art and Craft of Coinmaking. A history of minting technology (London: Spink \& Son 1988), 123-130.

47 Anonymous, "Verhandelingen der munten, maten, en gewigten, van Neerlandsch Indië," Verhandelingen van het Bataviaasch Genootschap, der kunsten en wetenschappen 6 (1824): 284-86.

48 For the most detailed overview of minting activity during the British interregnum, see Moquette, "De munten," pp. 33-96, on 53, 62 and 81 (list of names) (see note 42).

49 Ibid., pp. 33-96, appendix G.

50 See article seven of his instructions, which are reprinted in Van der Kemp "De zilveren Java-Ropijen," appendix B (see note 39). 

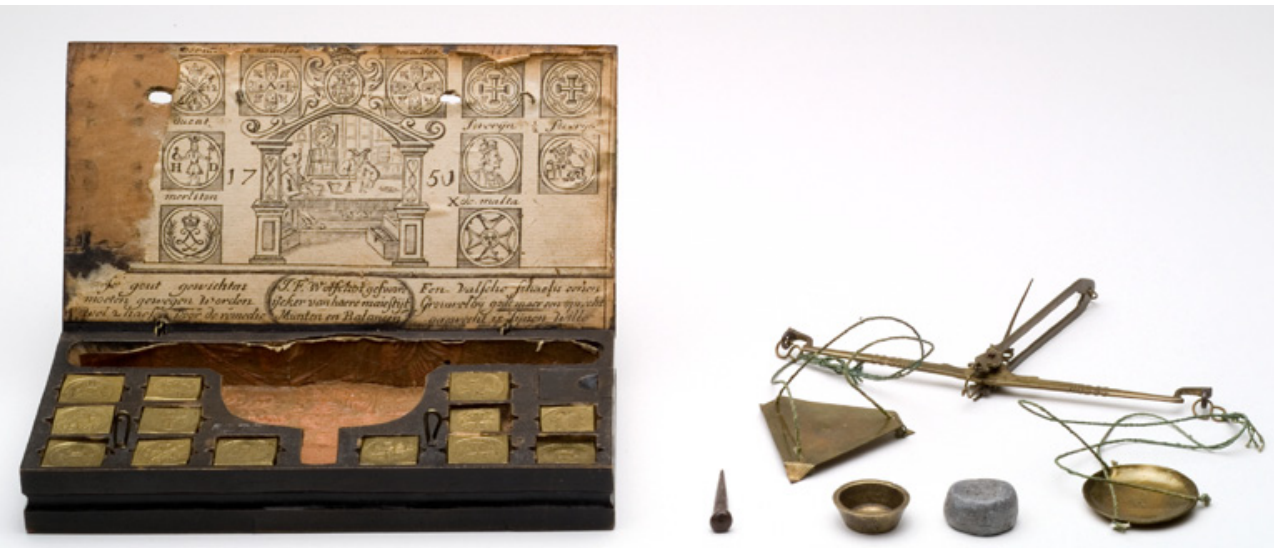

FIGURE 8.3 Balance used for the weighing of coins, eighteenth century. IMAGE USED BY THE KIND PERMISSION OF MUSEUM BOERHAAVE, LEIDEN.

also formed, as already explained, a threat to the status and capital of the colony's elite, who were - next to the colonial government - Zwekkert's most important customers. Zwekkert ingeniously managed to accommodate the interests of both these local clients and the distant government demands of Goldberg. He informed his superiors in Batavia that he was willing to produce silver rupees with a lower value of silver (9.614 grams) for the colonial government. But he actually used his chemical expertise to increase the silver content to the British norm (10.896 gram of fine silver), appropriating Goldberg's project for ends that protected the interests of his valued local customers.

After Zwekkert had confirmed the government's orders, he first used government funds to increase the mint's personnel. ${ }^{51}$ While Goldberg, the government minister, had struggled to secure experts in assaying and minting in the Netherlands, Zwekkert was well-placed to find suitable skilled support, since he was linked to various networks of artisans in the relevant trades. Zwekkert assembled a group with a deep understanding of how subtle material qualities in coins would effect their success as a currency. Owing to Surabaya's function as an important trading hub in the eastern part of the Indonesian Archipelago, the city housed skilled artisans such as cupel makers

On Zwekkert see Frederik de Haan, "Personalia der periode van het Engelsch bestuur over Java 1811-1816," Bijdragen tot de Taal-, Land-en Volkenkunde in Nederlandsch-Indië 92 (1935): $477-681$, on 669 . 


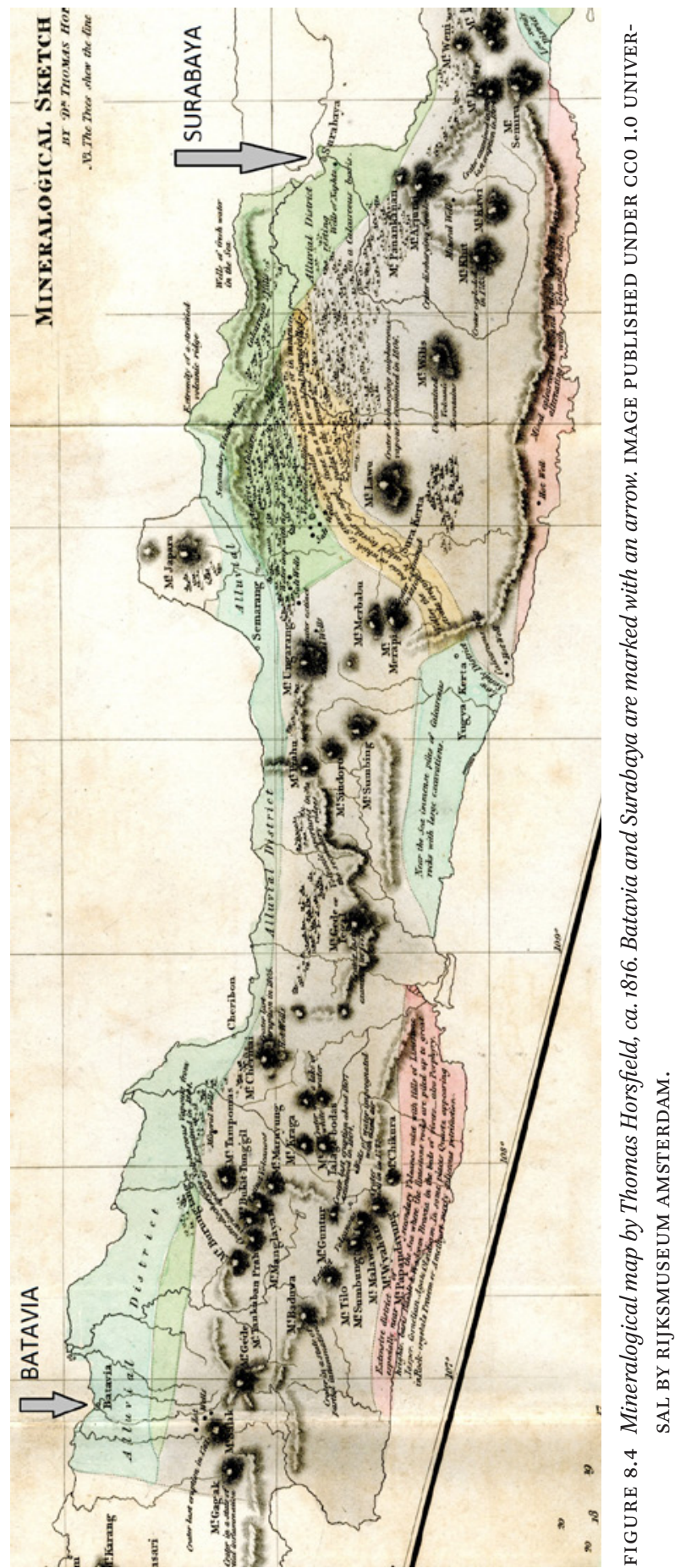


from China and Javanese engravers. ${ }^{52}$ Cupels (the shallow containers in which assays were carried out), together with assay balances, were crucial for the production of silver coins. ${ }^{53}$ Before the raw materials were brought to the mint's forge, Zwekkert used them to determine the exact amount of fine silver which was necessary for the production of the new rupees. Next to local cupel makers, Zwekkert also relied on the services of the Javanese engraver Inche Maimin and four of his local helpers. Besides having a thorough material expertise, engravers such as Inche Maimin also had to be knowledgeable experts on local monetary culture. Coins such as the rupee had to display a convincing combination of linguistic and visual features in order to be accepted as a medium of exchange for local and long-distance trade. Each coin carried Arabic characters on one side and Javanese characters on the other side. Maimin used rupees produced by the British in India as a visual guide. ${ }^{54}$ Zwekkert went to great efforts to enlist these highly skilled cupel makers and engravers, offering them permanent and well-paid positions. ${ }^{55}$ In order to emphasize Maimin's role in relation to local money users, his initial $(\mathrm{M})$ was struck on every Java rupee.

Zwekkert thus went to some lengths to enact a version of Goldberg's policy that reshaped it to serve his own ends and the interests of his private clients. It afforded him improvements to his premises and personnel, but also the opportunity to alter policy. This only became apparent to the government in mid-1817, after he had handed in detailed balance sheets. When government officials in Batavia and The Hague started to compare the amount of produced coins with the amount of silver which was sent to Surabaya, they gradually realized that Zwekkert had minted a currency that contained much more fine silver than

$5^{2}$ Ulbe Bosma, The Sugar Plantation in India and Indonesia. Industrial production, 1770-2010 (Cambridge: Cambridge University Press, 2013), 107. For a fascinating insight into the Javanese metal industry, Gerret P. Rouffaer, De voornaamste industrieën der inlandsche bevolking van Java en Madoera ('s-Gravenhage: Martinus Nijhoff, 1904), 91-122. For the growing role of Chinese traders in the region, Kwee H. Kian, "The Expansion of Chinese InterInsular and Hinterland Trade in Southeast Asia, c. 1400-1850," in David Henley and Henk Schulte Nordholt, eds., Environment, Trade and Society in Southeast Asia (Brill: Leiden, 2015), 149-165.

For an in-depth description of the process, see Cooper, The Art and Craft, pp. 85-87 (see note 46$)$.

54 Scholten, De munten, p. 84 (see note 15).

55 Van der Kemp, "De zilveren Java-Ropijen," pp. 299-301 (see note 39) and Moquette, "De munten," appendix U (see note 42). From December 1816 to June 1817, Maimin received 384 rupees. High-quality dyes were the best protection against forgery. See also G.P. Dyer and P.P. Gaspar, "Reform, the New Technology and Tower Hill, 1700-1966," in C.E. Challis, ed., A New History of the Royal Mint (Cambridge: Cambridge University Press, 1992), 398-606, on 409 . 
TABLE 8.1 Comparing the fine metal content of silver coins involved in Goldberg's reform program. Of course, the real content of fine metal varied greatly. One ace (aas) is the equivalent of 0.048 gram. FOR DETAILS, SEE J.H. VAN SWINDEN, BEDENKINGEN OVER HET MUNTWEZEN (UTRECHT: HET GELDMUSEUM, 1997), IV.

\begin{tabular}{|c|c|c|c|c|}
\hline & $\begin{array}{l}\text { Silver money in } \\
\text { the Netherlands } \\
(1815) \\
\text { (guilder) }\end{array}$ & $\begin{array}{l}\text { Silver money in } \\
\text { the colonies as } \\
\text { projected by } \\
\text { Goldberg in } 1816 \\
\text { (colonial guilder) }\end{array}$ & $\begin{array}{l}\text { Silver money } \\
\text { produced by } \\
\text { the British } \\
\text { (rupee) }\end{array}$ & $\begin{array}{l}\text { Silver money as } \\
\text { produced by } \\
\text { Zwekkert in } \\
\text { Surabaya in } \\
1816 / 1817 .\end{array}$ \\
\hline $\begin{array}{l}\text { Amount of fine } \\
\text { silver in aces } \\
\text { (rounded) }\end{array}$ & 200 aces & 166 aces & 227 aces & 227 aces \\
\hline $\begin{array}{l}\text { Amount of fine } \\
\text { silver in gram } \\
\text { (rounded) }\end{array}$ & 9.6 gram & 7.968 gram & 10.896 gram & 10.896 gram \\
\hline $\begin{array}{l}\text { Estimation of } \\
\text { coins minted from } \\
1 \text { kg of fine silver } \\
\text { (excluding loss } \\
\text { caused by melting, } \\
\text { etc.) }\end{array}$ & $\sim 104$ coins & $\sim 125$ coins & $\sim 91$ coins & $\sim 91$ coins \\
\hline
\end{tabular}

Owing to Zwekkert's reluctance, roughly 27 percent fewer silver coins were produced than Goldberg and the Dutch crown had projected in 1816 .

either Goldberg or the government in Batavia had planned. ${ }^{56}$ Since Zwekkert was using more silver in each coin, the total he produced with the silver sent from abroad turned out to amount to only some 75 percent of the desired quantity (Table 8.1). Producing 26o,ooo silver rupees in Surabaya thus increased the costs for the new money tremendously. Instead of helping to mitigate public debt at home, the production of the currency actually increased the public debt.

The reactions to these developments were harsh. The colonial government in Batavia immediately stopped the production of silver coins in Surabaya. It then intervened directly with the mint's organization. According to regulations of 1819, the mint master had to report on his activity on a weekly basis in order

$5^{6} \quad$ Van der Kemp, “De zilveren Java-Ropijen," pp. 303-4 (see note 39). 
to compensate for the high costs the minting of the silver rupees had created. ${ }^{57}$ The mint master responded by claiming that the silver which Goldberg had sent to Batavia must have had a much lower silver content than metal traders in Europe had promised. But this did not alter the government's distrust of the mint. ${ }^{58}$ Until its dissolution in 1843 , the mint in Surabaya was never again asked to mint silver or gold coins for the colonial government. ${ }^{59}$

Material accommodations to diverse local interests over coinage in Java thus led to radical consequences for Goldberg's policy at home. Back in the Netherlands, Zwekkert's behavior and the colonial government's inability to discipline the mint's activities had fatal consequences for Goldberg's career and the treasury. Instead of maintaining his position in the king's inner circle of advisors, Goldberg was shifted to a less influential position as the king decided to dissolve the Department of Trade and Colonies. While the Dutch crown had first followed Goldberg's plan to introduce the new currency in the form of paper bills and coins with silver content far below the local norm, the king eventually opted for a less costly form of managing the colony's agricultural wealth. In order to realign the interests of proto-bankers in Batavia and at home, the Crown invited them to become shareholders in a new trading company, the so-called Netherlands Trading Society (Nederlandsche HandelMaatschappij, or NHM). ${ }^{60}$ In order to attract private capital, the NHM was awarded exclusive rights to ship cash crops and other products from and to the Indonesian Archipelago. Moreover, the king guaranteed a dividend of 4.5 percent for each share. On the day the shares were issued, wealthy individuals invested almost 70 million guilders. ${ }^{61}$ Unlike Goldberg's attempt to reduce colonial debt by introducing a new paper currency, the NHM was an instant success because it allowed the Dutch crown to capitalize on the colony's agricultural riches. In 1840 , a caricaturist had to remind the Dutch public of the opportunities merchants in Batavia once had. In order to symbolize the dominant role of the NHM, the anonymous cartoonist depicted the trading company as a sea monster controlling all ships going to and from Batavia. Seen from the

57 See the instructions of the mint master and other personnel: ANRI Jakarta, K 20 Surabaya, 1254: Ingekomen brieven bij de muntmeester te Surabaya 1818: Reglement op het beheer en de administratie van de munt in Surabaya.

$5^{8}$ ANRI Jakarta, Muntwezen, no. 7: Mint master to Resident of Surabaya: 15 June 1821.

59 Bucknill, The Coins, chapter 6 (see note 15).

6o Ton de Graaf, Voor handel en Maatschappij. Geschiedenis van de Nederlandsche HandelMaatschappij, 1824-1964 (Amsterdam: Boom, 2012), 39-45.

61 J. Jonker and K.E. Sluyterman, At Home on the World Markets: Dutch international trading companies from the 16th century until the present (The Hague: SDU Uitgevers, 2000), 160. 
cartoonist's perspective, the NHM had made the accumulation of private wealth in Batavia impossible. ${ }^{62}$

By following Goldberg's currency to Java, the second part of this essay has shown that the colony's mint master and the chemistry of coins played an active role in the formation and execution of monetary policy. Instead of passively serving his metropolitan masters, Zwekkert appropriated Goldberg's project for his own goals, which were shaped by the local networks of which he was a part. The consequences were not only felt in the colony but also at home. In order to counter the growing cost of colonial management, the king resorted to an alternative form of monetary policy. Instead of aiming to devalue private assets in Batavia, he invited wealthy individuals to invest capital in a new trading company which received extensive trading rights to and from the Indonesian Archipelago. By reformulating the government's orders, the colony's mint master thus prevented locally accumulated private capital from being used for the tremendous public debt which had accumulated in the Netherlands.

\section{Conclusion}

In the process of governing the Dutch colonies, metropolitan ministers may have been the first to enunciate policies, but their final shape and consequences depended on the practical contributions of a variety of people and contexts. In the case of Dutch coinage in Java, the embodied formation and enactment of policy hinged on chemical practices that the Dutch minister Goldberg was ill-equipped to manage. Making the new coinage work to relieve government debt hinged on material considerations of the quantity of silver to be incorporated into coins, which demanded the skilled assessments and labor of expert assayers, mint masters, and engravers. So too did they depend on familiarity with more locally situated social and cultural trends, manifested in coin design and designation, that afforded local acceptance of what was

62 A digital copy of the caricature, which was titled De Groothandelaar (The Wholesaler) may be found here: <http://hdl.handle.net/10934/RMooo1.ColLeCT.521867> [accessed February 22, 2015]. Of course, this is a very simplistic picture. Research by Roger Knight and Alex Claver has shown that the Indonesian Archipelago continued to offer a fertile climate for private entrepreneurs. See Roger Knight, "Rescued from the Myths of Time: Toward a reappraisal of European merchant houses in mid-nineteenth century Java, ca. 1830-1870," Bijdragen tot de Taal,- Land- en Volkenkunde 170 (2014): 313-341; Alex Claver, Dutch Commerce and Chinese Merchants in Java. Colonial relationships in trade and finance, 1800-1942 (Brill: Leiden, 2014). 
otherwise seen as foreign - and therefore untrustworthy - currency. Unable to secure such skills at home, Goldberg delegated the production of new coins to colonial masters, but in so doing had to defer control to persons and institutions that were even farther from his immediate reach. These did not serve him well. Attuned to a local economy whose moral and material evaluations of currency were quite at odds with those of the Dutch government, the Surabaya mint masters reworked the new currency to suit their own ends. The result was a devastating reversal of the intended policy, costing more money than might be saved, that ultimately prompted the fall of Goldberg himself.

Approached through the lens of chemical governance, the material dimensions of colonial government become apparent. In Goldberg's case, monetary policy depended on locally situated chemical expertise. Zwekkert used his expertise to increase the silver content of the newly produced coins. Since the exact composition of the coins initially remained invisible to the colonial government, he was able for a time to secure the mint's existence and counter the threat to the wealthy colonial elite's private capital and authority, which was embodied in the introduction of a new currency.

In conclusion, this chapter has shown how modes of government and scientific practice cannot be treated separately in understanding the relations of metropole and colony in this period. Rather, an understanding of chemical governance exposes a polycentric world in which power was dispersed amongst people, skills and practices. Far from simply enabling or constraining policy enforcement, local initiatives and acts of appropriation which were informed by chemical expertise shaped the realization of policies. These chemical acts have subsequently become obscure to historians interested in colonial governance, at least in part because it was ultimately Goldberg himself who was formally recognized as responsible for the policy's failure. Nonetheless, chemical practices that were pursued at various distances from the official center of metropolitan policymaking proved critical to the formative realization of both colonial and metropolitan governance.

\section{Acknowledgments}

I would like to thank Lissa Roberts, Simon Werrett, Joppe van Driel and Esther van Gelder for their comments on earlier versions of this essay. I would also like to thank Erik van der Kam, curator of the National Numismatic Collection in Amsterdam, for providing with me with some of the visual material used in this essay, and Johan de Zoete from Museum Enschede in Haarlem for information and bibliographical references about the production of paper money by Joh. Enschedé en Zonen. 